\title{
Genetic variation in Turkish honeybees Apis mellifera anatoliaca, A. m. caucasica, A. m. meda (Hymenoptera: Apidae) inferred from RFLP analysis of three mtDNA regions (16S rDNA-COI-ND5)
}

\author{
Fulya ÖZDIL, İBrahim AYTEKIN, FATMA İLHAN and SAIM BOZTEPE \\ Selçuk University, Faculty of Agriculture, Department of Animal Science, 42075 Konya, Turkey; \\ e-mails: fulyaozdil@selcuk.edu.tr; aytekin@selcuk.edu.tr; fatmailhan@selcuk.edu.tr; sboztepe@selcuk.edu.tr
}

Key words. Hymenoptera, Apidae, Apis mellifera, 16S rDNA, COI, ND5, PCR-RFLP, Turkey

\begin{abstract}
In this study, the genetic structure of Turkish honey bee (Apis mellifera L.) populations, mainly obtained from the Central Anatolian region, were investigated at three different mitochondrial regions. A total of 165 worker bees were collected from 15 different populations in ten different locations. Portions of the mitochondrial 16S ribosomal RNA (16S rDNA), cytochrome C oxidase I (COI) and NADH dehydrogenase 5 (ND5) genes were amplified by PCR and then subjected to RFLP pattern analysis using 18 restriction enzymes (these having at least one recognition site in each region were used). Nucleotide polymorphisms were revealed using restriction enzymes Bsp143I, DraI and $S s p \mathrm{I}$ in $16 \mathrm{~S}$ rDNA and TaqI in the COI gene segment. The polymorphisms were subsequently confirmed by direct DNA sequencing with sequences thereafter deposited in Genbank. In this study, six novel composite genotypes (haplotypes) were found in Turkish honey bee populations. The most common haplotype, type 1, was found in 12 of the sampled populations and overall accounted for $85.5 \%$ of the samples. TCS spanning network of haplotypes revealed that type 1 was the basal haplotype. Genetic distance $(D)$ values were found to be low $(0.0-0.0112)$ within Turkish honey bee populations. The average haplotype diversity $(h)$ within populations was 0.082 . Molecular phylogenetic analysis revealed that Konya/Sizma, Antalya/Elmalı and Konya/Selçuklu populations were the most distant from all the other Turkish honey bee populations surveyed.
\end{abstract}

\section{INTRODUCTION}

The western honey bee, Apis mellifera L., is native to Africa, the Near and Middle East, and Europe. Based on morphometric analysis, Ruttner (1988) grouped honey bee subspecies into four geographic branches: a south and central African branch (A), a north African and west European branch (M), an east European and north Mediterranean branch (C), and a Near and Middle Eastern branch (O). Subsequent studies using morphometry, along with mitochondrial DNA and microsatellite marker analysis, have confirmed or modified the species distributions within these groups and have added a new Middle Eastern branch from Yemen (Y) (Hall \& Smith, 1991; Arias \& Sheppard, 1996; Kauhausen-Keller et al., 1997; Smith et al., 1997; Palmer et al., 2000; Franck et al., 2000, 2001).

Based on morphometrics, the Near Eastern subspecies, Anatolian (A. m. anatoliaca), Caucasian (A. m. caucasica) and Iranian (A. m. meda), had been grouped within the O branch (Ruttner, 1988; Kauhausen-Keller et al., 1997, Adl et al., 2007); however, mtDNA analysis showed that they in fact belonged to the $\mathrm{C}$ lineage (Smith et al., 1997; Palmer et al., 2000; Franck et al., 2000, 2001; Özdil et al., 2009a, b; Bouga et al., 2011). From his morphometric analyses, Ruttner (1988) concluded that $A$. $m$. anatoliaca, A. $m$. caucasica, and A. m. meda all exist in Turkey. Nearly all of the geographical landmass of Turkey is seemingly occupied by $A$. $m$. anatoliaca, including European Turkey, except for the northeastern part where A. m. caucasica is found, whilst A. m. meda occurs in the southeastern part of the country. Recently, mitochondrial studies of Turkish honeybees have shown that $A . m$. carnica is also found in the Thrace region of European Turkey (Palmer et al., 2000), whilst A. $m$. syriaca is found in the southern part of the country near Hatay (Kandemir et al., 2006).

PCR-RFLP using mtDNA markers of honeybees have been particularly useful in differentiating evolutionary lineages and groups of subspecies (Hall \& Smith, 1991; Garnery et al., 1992, 1993; Franck et al., 2000; Palmer et al., 2000). PCR-RFLP with DraI restriction enzyme analysis of the cytochrome $\mathrm{C}$ oxidase $\mathrm{COI}$ and COII (COI-COII) intergenic region revealed more than 50 different haplotypes, mainly in lineages $\mathrm{A}$ and $\mathrm{M}$ and with less in lineage C (Garnery et al., 1992, 1993; Franck et al., 2000, 2001; Palmer et al., 2000; De la Rúa et al., 2006; Suppasat et al., 2007; Munoz et al., 2009; Nedic et al., 2009; Özdil et al., 2009a; Solorzano et al., 2009; Magnus \& Szalanski, 2010). More recently, the other mitochondrial regions including $16 \mathrm{~S}$ ribosomal DNA (rDNA) (Bouga et al., 2005; Collet et al., 2007; Kekeçoğlu et al., 2009), NADH dehydrogenase-2 (ND2) (Arias \& Sheppard, 1996; Kandemir et al., 2006), and NADH dehydrogenase-5 (ND5) regions (Bouga et al., 2005; Martimianakis et al., 2011; Özdil et al., 2012), along with the COI region (Tanaka et al., 2001; Bouga et al., 2005; Kekeçoğlu et al., 2009; Sheffield et al., 2009; Martimianakis et al., 2011), were used to differentiate evolutionary lineages and groups of honey bee subspecies. 


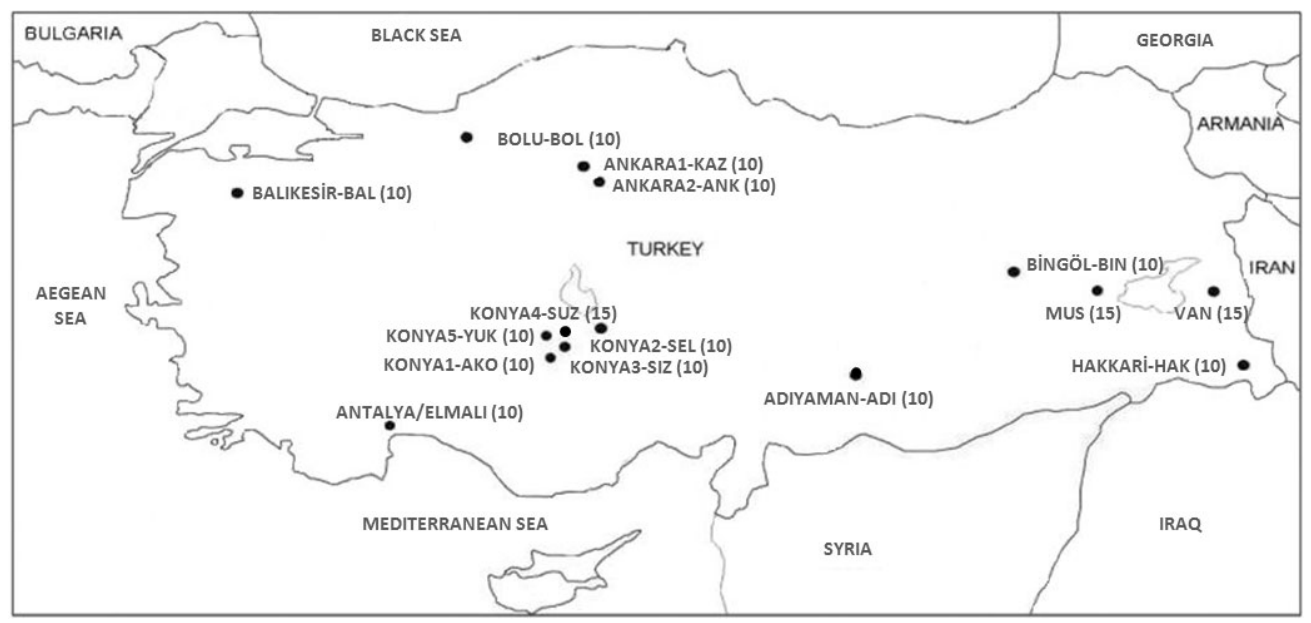

Fig. 1. Sampling locations of honey bees in Turkey. The number bracketed in parenthesis shows the number of colonies analyzed at each site.

The objective of the present research was to determine the level of genetic differentiation among and between Turkish honeybee populations as discriminated using PCR-RFLP pattern analysis of the $16 \mathrm{~S}$ rDNA, COI and ND5 gene regions. mtDNA length variation and levels of genetic diversity as found in this study were compared with the results of other earlier mitochondrial studies of honey bees, such comparison thereby allowing much more complete assessment of the genetic structure of Turkish honey bee populations than hitherto previously possible using morphometrics alone.

\section{MATERIAL AND METHODS}

\section{Sampling of the honeybees}

Worker honey bees were collected between May 2008 and September 2009 from a total of 165 colonies from 15 different populations in ten different locations in Turkey (Fig. 1, Table 1). One sample was taken from each colony, these deriving from established colonies maintained by local (i.e. "none migratory") beekeepers. These samples were used for PCR-RFLP analysis of the three mtDNA regions studied.

\section{DNA isolation}

Worker bees were individually placed in $1.5 \mathrm{~mL}$ Eppendorf tubes containing $1.0 \mathrm{~mL}$ of $95 \%$ ethanol for transportation to the laboratory. Before DNA extraction, bees were rinsed in distilled water and air dried for about half an hour. Total genomic DNA was extracted from single bee thoraces according to Hall (1990). The concentration and purification of genomic DNA was quantified using a NanoDrop ND-1000 (Thermo Fisher Scientific, Inc. Wilmington, Delaware, USA) spectrophotometer, and $20 \mathrm{ng}$ of genomic DNA was used for the PCR.

\section{RFLP Analysis}

Mitochondrial regions were amplified according to Bouga et al. (2005). Three sets of primers were used for amplifying 16S rDNA, COI and ND5 gene regions, respectively. These were 5'CAACATCGAGGTCGCAAACATC-3' and 5'-GTACCTTTT GTATCAGGGTTGA-3' for 16S rDNA, 5'-GATTACTTCCTC CCTCATTA-3' and 5'-AATCTGGATAGTCTGAATAA-3' for COI and 5'-TCGAAATGAATAGGATACAG-3' and 5'GGTTGAGATGGTTTAGGATT-3' for the ND5 segment. PCR was run in a total volume $25 \mu 1$ of the following reaction mixture: $2.5 \mu$ of $10 \times$ reaction buffer with $\mathrm{KCl}$ as provided by the manufacturer (Fermentas Life Sciences, Vilnius, Lithuania), 2

TABLE 1. Sampling localities, geographical positions and number of colonies used for RFLP analyses.

\begin{tabular}{|c|c|c|c|c|}
\hline \multirow{2}{*}{$\frac{\text { Locations }}{\text { Adiyaman }}$} & \multirow{2}{*}{$\frac{\text { Abbreviation of the locations }}{\text { ADI }}$} & \multicolumn{2}{|c|}{ Geographical position } & \multirow{2}{*}{$\begin{array}{c}\text { \# Colonies analyzed for RFLP analysis } \\
10\end{array}$} \\
\hline & & $37^{\circ} 46^{\prime} \mathrm{N}$ & $38^{\circ} 16^{\prime} \mathrm{E}$ & \\
\hline Ankara1 / Kazan & KAZ & $39^{\circ} 58^{\prime} \mathrm{N}$ & $32^{\circ} 52^{\prime} \mathrm{E}$ & 10 \\
\hline Ankara2 & ANK & $40^{\circ} 12^{\prime} \mathrm{N}$ & $32^{\circ} 41^{\prime} \mathrm{E}$ & 10 \\
\hline Antalya / Elmalı & ELM & $36^{\circ} 44^{\prime} \mathrm{N}$ & $29^{\circ} 56^{\prime} \mathrm{E}$ & 10 \\
\hline Balıkesir & BAL & $39^{\circ} 39^{\prime} \mathrm{N}$ & $27^{\circ} 53^{\prime} \mathrm{E}$ & 10 \\
\hline Bingöl & $\mathrm{BIN}$ & $39^{\circ} 00^{\prime} \mathrm{N}$ & $40^{\circ} 41^{\prime} \mathrm{E}$ & 10 \\
\hline Bolu / Yı̆̆glca & BOL & $40^{\circ} 58^{\prime} \mathrm{N}$ & $31^{\circ} 27^{\prime} \mathrm{E}$ & 10 \\
\hline Hakkari & HAK & $37^{\circ} 35^{\prime} \mathrm{N}$ & $43^{\circ} 34^{\prime} \mathrm{E}$ & 10 \\
\hline Konya1 / Akören & $\mathrm{AKO}$ & $37^{\circ} 27^{\prime} \mathrm{N}$ & $32^{\circ} 22^{\prime} \mathrm{E}$ & 10 \\
\hline Konya2 / Selçuklu & SEL & $37^{\circ} 57^{\prime} \mathrm{N}$ & $32^{\circ} 26^{\prime} \mathrm{E}$ & 10 \\
\hline Konya3 / Sizma & SIZ & $38^{\circ} 05^{\prime} \mathrm{N}$ & $32^{\circ} 24^{\prime} \mathrm{E}$ & 10 \\
\hline Konya4 & SUZ* & $38^{\circ} 02^{\prime} \mathrm{N}$ & $32^{\circ} 30^{\prime} \mathrm{E}$ & 15 \\
\hline Konya5 / Yükselen & YUK & $38^{\circ} 04^{\prime} \mathrm{N}$ & $32^{\circ} 20^{\prime} \mathrm{E}$ & 10 \\
\hline Muş / Varto & MUS & $39^{\circ} 17^{\prime} \mathrm{N}$ & $41^{\circ} 12^{\prime} \mathrm{E}$ & 15 \\
\hline Van / Gevaş & VAN & $38^{\circ} 18^{\prime} \mathrm{N}$ & $43^{\circ} 06^{\prime} \mathrm{E}$ & 15 \\
\hline Total & & & & 165 \\
\hline
\end{tabular}

*SUZ - The Apiary of the Selçuk University. 


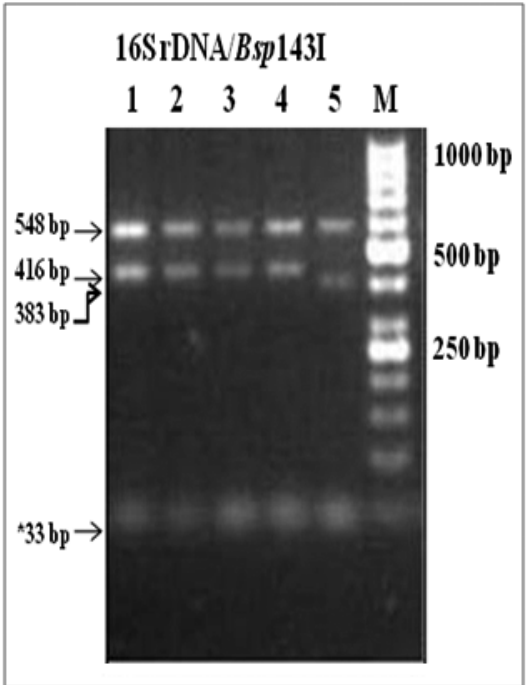

a

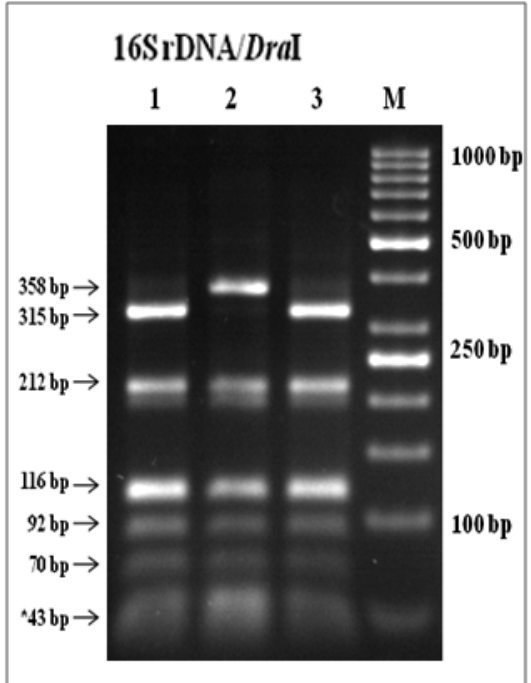

b

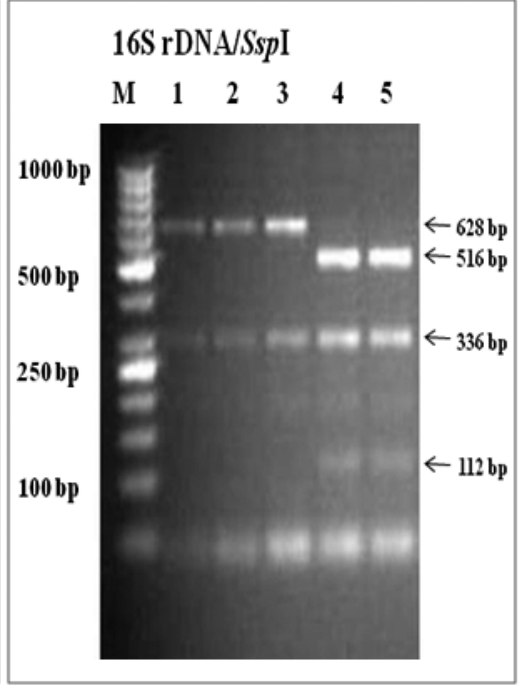

c

Fig. 2. Bsp 143I, DraI and SspI restriction patterns found in $16 \mathrm{~S}$ rDNA gene regions of Turkish honey bee samples. a - Bsp 143I digestion of $16 \mathrm{~S}$ rDNA gene segment, lane 1-4: B type (548, $416 \mathrm{bp})$, lane 5: C type (548, 383, $33 \mathrm{bp})$; b - DraI digestion of $16 \mathrm{~S}$ rDNA gene segment, lane 1-3: C type $(315,212,116,116,92,70,43 \mathrm{bp})$, lane 2: D type $(358,212,116,116,92,70 \mathrm{bp})$; c - SspI digestion of $16 \mathrm{~S}$ rDNA gene segment, lane 1-3: A type (628, $336 \mathrm{bp})$, lane 4-5: B type (516, 336, $112 \mathrm{bp})$. M - DNA size marker.

$\mathrm{mM} \mathrm{MgCl} 2,2 \mathrm{mM}$ of dNTP mix, $0.5 \mu \mathrm{M}$ of each primer, $2 \mathrm{U}$ of Taq polymerase and $20 \mathrm{ng}$ of total purified honey bee DNA. For each primer pair, the following reaction profile was used: initial denaturation $94^{\circ} \mathrm{C}$ for $4 \mathrm{~min}, 35$ cycles of $94^{\circ} \mathrm{C}$ for $1 \mathrm{~min}$, annealing at $55^{\circ} \mathrm{C}\left(16 \mathrm{~S}\right.$ rDNA and COI) or at $50^{\circ} \mathrm{C}$ (ND5) for 1 min, and extension at $72^{\circ} \mathrm{C}$ for $2 \mathrm{~min}$, followed by a final extension step at $72^{\circ} \mathrm{C}$ for $15 \mathrm{~min}$.

The amplified products obtained were next electrophoresed on $1 \%$ agarose gel to verify the size of the fragment. Amplified mtDNA regions from two individuals of each population were digested with 18 restriction enzymes to check for the presence of recognition sites. The informative restriction enzymes were then analyzed using ten to fifteen individuals from each population. The informative restriction enzymes used for the $16 \mathrm{~S}$ rDNA gene fragment were: AluI, Bsp143I (Sau3AI), DraI, EcoRI, HincII, HphI, PstI, SspI, TaqI, VspI (AseI); for the COI gene fragment AluI, BclI, BseGI (FokI), Bsp143I (Sau3AI),
$H p h \mathrm{I}, S s p \mathrm{I}, T a q \mathrm{I}, X h o \mathrm{I}$, and for the ND5 gene fragment AluI, DraI, RsaI, SspI, TaqI and VspI (AseI).

The digested fragments were separated electrophoretically on $2 \%$ or $3 \%$ agarose gels in $1 \times$ TBE buffer, stained with ethidium bromide and photographed using a Vilber Lourmat gel imaging system. DNA fragment sizes were determined using Digital Image analysis software (Vilber Lourmat Deutschland $\mathrm{GmbH}$ Eberhardzell, Germany). The different restriction fragments detected were sequenced on an ABI Prism 310 automated sequencer (Applied Biosystems, Foster City, CA, USA) using standard protocols in order to verify the sequence variations. Sequences were aligned with the computer program Clustal $\mathrm{X}$ (Thompson et al., 1997).

\section{Data analysis}

Composite genotypes (haplotypes) for each individual were grouped from all the restriction patterns of the three mtDNA

TABLE 2. Restriction fragment patterns generated from analysis of 16S rDNA gene segment of Turkish honey bees.

\begin{tabular}{|c|c|c|c|c|c|}
\hline \multicolumn{2}{|r|}{$16 \mathrm{~S}$ rDNA } & \multicolumn{2}{|r|}{$\mathrm{COI}$} & \multicolumn{2}{|r|}{ ND5 } \\
\hline $\begin{array}{l}\text { Restriction } \\
\text { enzyme }\end{array}$ & Patterns observed (bp) & $\begin{array}{l}\text { Restriction } \\
\text { enzyme }\end{array}$ & Patterns observed (bp) & $\begin{array}{l}\text { Restriction } \\
\text { enzyme }\end{array}$ & Patterns observed (bp) \\
\hline AluI & B: $507,392,65$ & $A l u \mathrm{I}$ & A: 728,300 & $A l u \mathrm{I}$ & C: $554,211,57$ \\
\hline 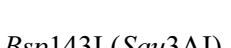 & B: 548,416 & $B c l I$ & C: $462,317,249$ & DraI & B: $440,270,112$ \\
\hline Bsp 1431 (गаusA) & C: $548,383,33$ & BseGI (FokI) & B: $631,318,79$ & $R s a \mathrm{I}$ & A: 792,30 \\
\hline DraI & C: $315,212,116,116,92,70,43$ & Bsp143I (Sau3AI) & B: $340,317,171,78,77,45$ & Ssp I & B: $401,192,93,82,54$ \\
\hline Drat & D: $358,212,116,116,92,70$ & $H p h \mathrm{I}$ & A: 925,103 & TaqI & B: $279,240,205,98$ \\
\hline EcoRI & B: 483,481 & Ssp I & C: $523,213,175,85,32$ & VspI (AseI) & A: $228,217,198,114,65$ \\
\hline HincII & B: 584,380 & & A: $432,352,244$ & & \\
\hline$H p h \mathrm{I}$ & A: 490,474 & $\operatorname{Taq} \mathrm{I}$ & B: $352,262,244,170$ & & \\
\hline Pst $\mathrm{I}$ & B: 573,391 & XhoI & A: 616,412 & & \\
\hline Ssp I & $\begin{array}{l}\text { A: } 628,336 \\
\text { B: } 516,336,112\end{array}$ & & & & \\
\hline Taq I & A: 545,419 & & & & \\
\hline Vsp I (AseI) & A: $320,243,143,129,76,53$ & & & & \\
\hline
\end{tabular}




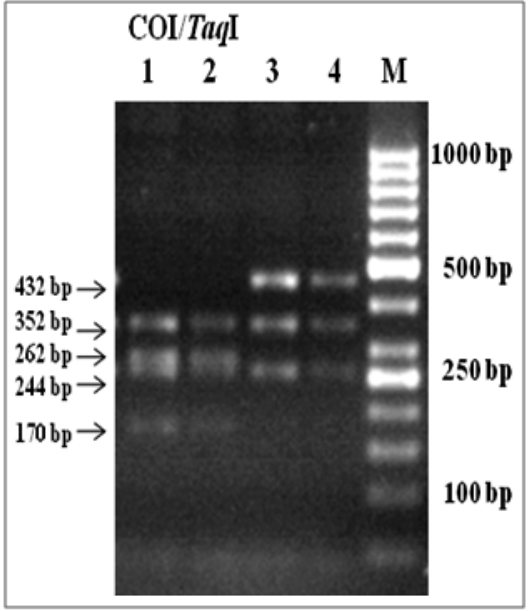

$\mathbf{a}$

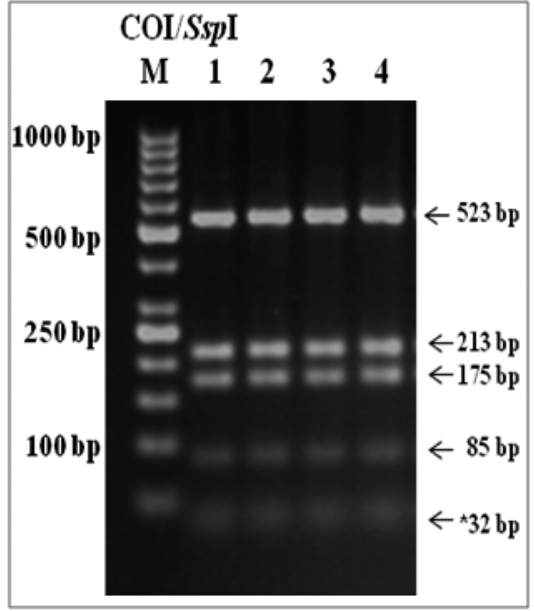

b

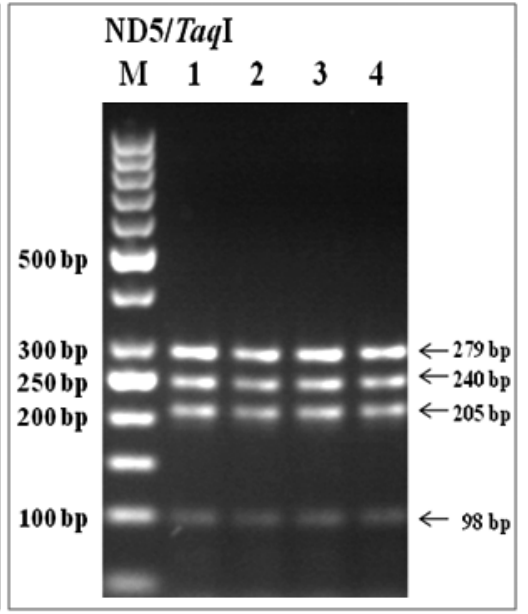

c

Fig. 3. TaqI restriction patterns in COI and ND5 genes and $S s p$ I restriction pattern in COI gene region of Turkish honey bee samples. a - TaqI digestion of COI gene segment, lane 1-2: B type (352, 262, 244, $170 \mathrm{bp})$, lane3-4: A type (432, 352, $244 \mathrm{bp})$; b - SspI digestion of COI gene segment, lane 1-4: C type $(523,213,175,85,32)$; c - TaqI digestion of ND5 gene segment, lane 1-4: B type $(279,240,205,98)$. M - DNA size marker.

amplicons tested. Haplotype diversity between populations was estimated according to Nei \& Tajima (1981) and Nei (1987). Genetic distances (Nei, 1978) among haplotypes and frequency distribution among and between populations were calculated using the Restriction Enzyme Analysis Package REAP (McElroy et al., 1991).

While Neighbor-Joining, Maximum Parsimony and Maximum Likelihood methods all have difficulties in resolving relationships among closely related haplotypes, statistical parsimony allows display of genealogical relationships among sequences with a limited number of mutations. The results of statistical parsimony among six haplotypes were represented using a network calculated with TCS version 1.21 software (Clement et al., 2000).

\section{RESULTS}

The sizes of the PCR-amplified mtDNA regions for all populations studied were found to average $964 \mathrm{bp}$ for $16 \mathrm{~S}$ rDNA, 1028 bp for COI and 822 bp for ND5 mtDNA gene regions. Ten, eight and six restriction enzymes were found to have at least one restriction site in the amplified 16S rDNA, COI and ND5 regions, respectively. Observed fragment patterns generated by each restriction enzyme for the three mtDNA regions are summarized in Table 2.
Bsp143I, DraI and SspI restrictions in 16S rDNA (Fig. 2) and TaqI restriction in the COI gene each generated two different restriction profiles in Turkish honeybees (Fig. 3).

Diagnostic and novel patterns were revealed in the Konya/Sizma (SIZ) and Antalya/Elmalı (ELM) populations after the digestion of $16 \mathrm{~S}$ rDNA segment with the restriction enzyme $B s p 143$ I (pattern type C). The nucleotide sequences of the pattern type B and type C of $16 \mathrm{~S}$ rDNA gene segment (Fig. 2) were deposited in Genbank with accession numbers JF825878 and JF825879, respectively. In the pattern type $\mathrm{B}, \mathrm{a} \mathrm{C} \rightarrow \mathrm{T}$ transition was found at position 13513 that creates the additional Bsp143I restriction site (Fig. 4).

Moreover digestion of $16 \mathrm{~S}$ rDNA with the restriction enzyme DraI produced two novel restriction patterns (pattern type $\mathrm{C}$ and $\mathrm{D}$ ) which have not been reported previously (Fig. 2). Thus five or six DraI restriction sites were found in $16 \mathrm{~S}$ rDNA gene segment. In pattern type $\mathrm{C}$, six diagnostic restriction sites were found, and this pattern was seen to be the most common type in Turkish honey bees, whereas pattern type D lacked a DraI restriction site and was only found in some of the

TABLE 3. Composite genotypes (haplotypes), haplotype diversity and sample size of all the populations studied.

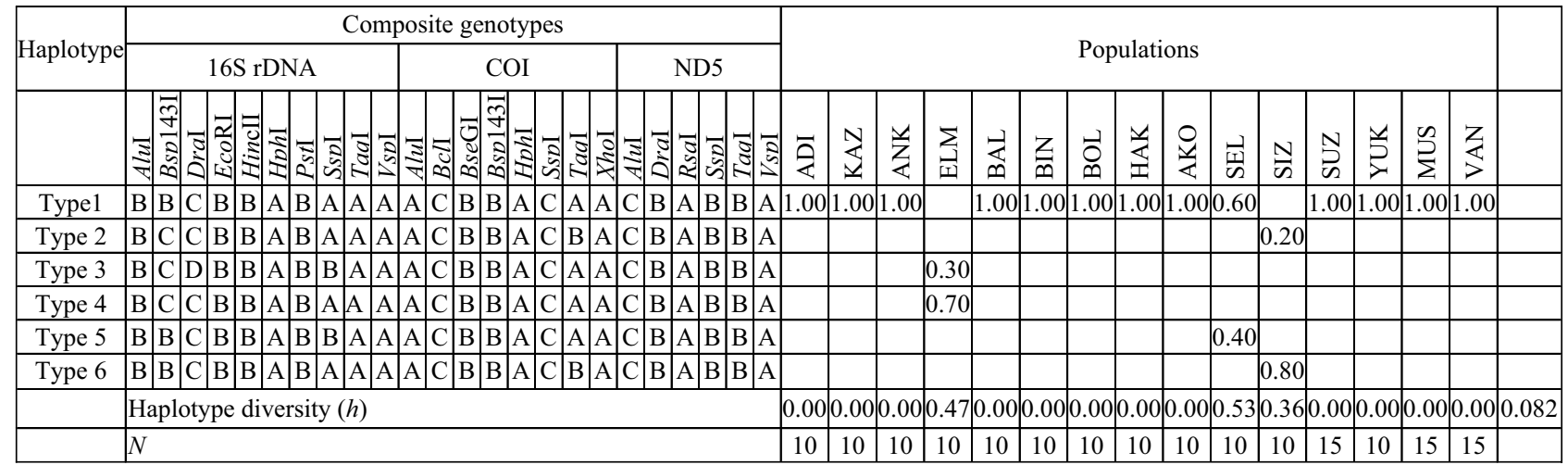




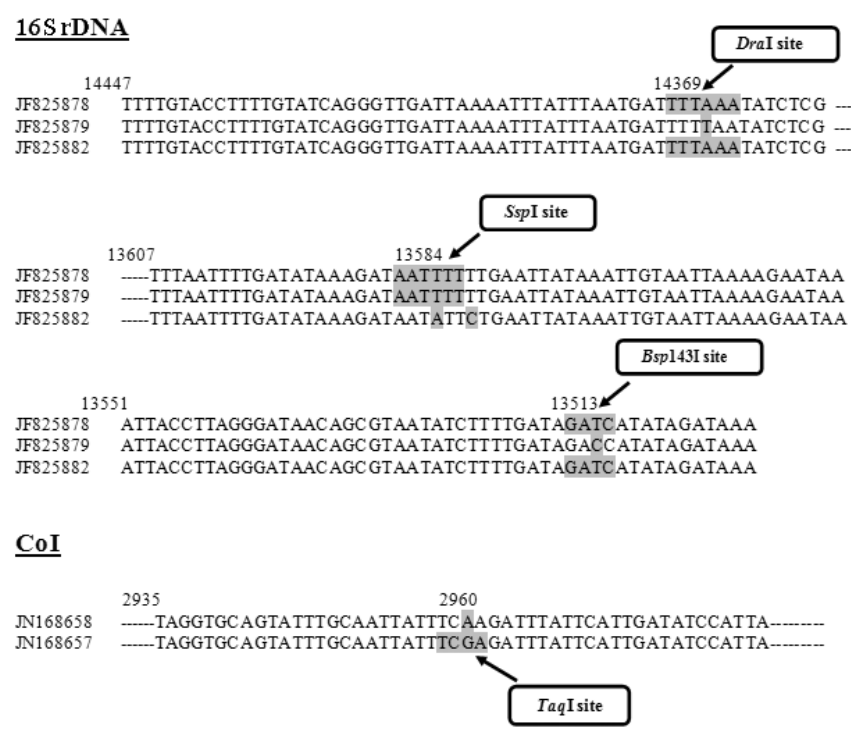

Fig. 4. Nucleotide variations of different restriction sites found to be polymorphic in this study.

Antalya/Elmalı (ELM) populations tested. An $\mathrm{A} \rightarrow \mathrm{T}$ transversion deleted one of the DraI restriction site at position 14369, the nucleotide sequences of the pattern type $\mathrm{D}$ of the $16 \mathrm{~S}$ rDNA gene region being deposited in Genbank with accession number JF825879 (Fig. 4).

Diagnostic patterns were also revealed in the Konya/Selçuklu (SEL) and Antalya/Elmalı (ELM) populations after the digestion of $16 \mathrm{~S}$ rDNA region with the restriction enzyme $S s p$ I (pattern type B) (Fig. 2), a result compatible with Bouga et al. (2005). $\mathrm{T} \rightarrow \mathrm{A}$ transversion at position 13584 deleted an $S s p$ I restriction site; this sequence was deposited in Genbank with accession number JF825882 (Fig. 4). A $\mathrm{T} \rightarrow \mathrm{C}$ transition at position 13587 was also found in JF825882.

Digestion of COI segment with the restriction enzyme TaqI produced different restriction pattern (pattern type B) from the Konya/Sizma (SIZ) population, a pattern that have not been observed before (Fig. 3). An $A \rightarrow G$ transition at position 2960 produced an additional TaqI restriction site; this sequence was deposited in Genbank with accession number JN168657 (Fig. 4).

The six different and novel haplotypes (composite genotypes) which were detected in the fifteen populations studied and the haplotype frequencies and haplotype diversity values are presented in Table 3. Type 1 haplotype was the most common haplotype, found in $85.5 \%$ of samples. Rarer haplotypes, type 2-6, type 3-4 and type 5, were found in Konya/Sizma (SIZ), Antalya/Elmalı (ELM) and Konya/Selçuklu (SEL) samples, respectively.

TCS spanning network of haplotypes revealed that type 1 was the basal haplotype and type 3 was the most distantly related to type 1 , with three base pair differences, and only occurred in the Antalya/Elmali population (Fig. 5).

The genetic distance $(D)$ values were found to be low $(0.0-0.0112)$ within Turkish honey bee populations. The average haplotype diversity $(h)$ within populations was 0.082 .

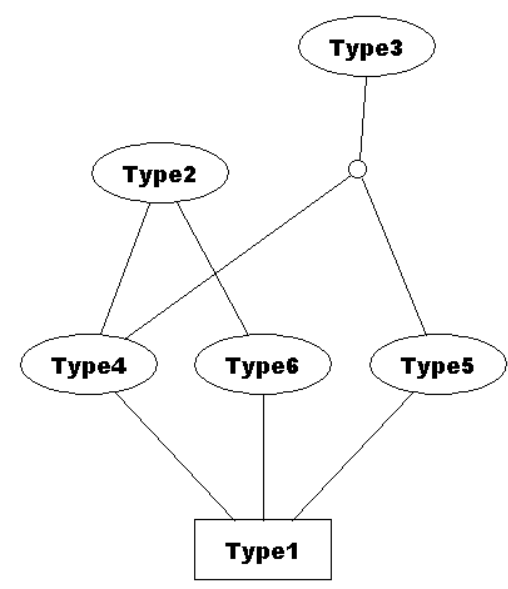

Fig. 5. Statistical parsimony network (TCS software, version 1.21) based on concatenated data sets of $16 \mathrm{~S}$ rDNA and COI sequences (1992 bp, 5 parsimony informative sites).

\section{DISCUSSION}

In a recent study of Turkish honey bee samples, we earlier showed that all insects then tested belonged to the East Mediterranean (C) lineage as found using several restriction enzymes (Özdil et al., 2009a). In the present study, we have used different regions of the mitochondrial genome to verify the nature and distribution of genetic variation within and between Turkish honey bee populations.

When we compare our results with Bouga et al. (2005) and Kekeçoğlu et al. (2009), we find similar restriction profiles with generally small base differences in the fragments, except for DraI, SspI and TaqI digestions in 16S rDNA, COI and ND5 gene regions, respectively (Table $2)$. In these regions, different restriction profiles were detected in our samples (Figs 2 and 3). DraI restriction in $16 \mathrm{~S}$ rDNA revealed five or six restriction sites in this study whereas, restriction analyses were previously reported to have revealed one or null restriction sites (Bouga et al., 2005, Kekeçoğlu et al., 2009). Following SspI digestion, four restriction sites were also found in the COI region (Fig. 3), a result contrasting with the one or two sites previously reported in earlier studies (Bouga et al., 2005; Kekeçoğlu et al., 2009). Similarly, the restriction of the ND5 gene region with TaqI revealed three sites (Fig. 3), compared with the two as reported in Greek honeybees (Bouga et al., 2005). The results of the present study were confirmed with complementary sequencing studies performed in order to check for the presence or absence of the restriction sites. The nucleotide polymorphisms responsible for the different restriction profiles were subsequently submitted to Genbank (JF825878, JF825879, JF825882 and JN168657, JN168658)

Overall, two main groups of haplotypes were detected among the six haplotypes from Turkish honey bee populations. The first haplotype (Type 1) was characteristic of nearly all Turkish honey bee populations analyzed $(85.5 \%)$ except for the Southern part of Turkey, characterized by the remaining haplotypes (Type 2-6). In terms of subspecies, A. m. caucasica (KAZ, ANK) and A. $m$. 
meda (ADI, BIN, HAK, MUS, VAN) ecotypes were found to show Type 1 haplotype, whereas A. m. anatoliaca ecotypes from southern and central region displayed the remaining haplotypes (Type 2 to 6). Type 2-6, type 3-4 and type 5, were found in Konya/Sizma (SIZ), Antalya/Elmali (ELM) and Konya/Selçuklu (SEL) samples, respectively. The provinces of Konya and Antalya are found in the central and southern part of Turkey and are close to each other. These two regions are dominated by $A$. $m$. anatoliaca and $A$. $m$. anatoliaca ecotypes, so the existence of unique haplotypes in Konya/Sizma-SIZ (Type 2 and 6) and Antalya/Elmal1-ELM (Type 3 and 4) populations at high frequencies could be attributed to different founder queens since beekeepers from these two regions do not use commercial $A$. $m$. caucasica queens. However, further follow up studies are needed to characterize mitochondrial DNA variation in the honeybees of these regions along with morphometric analyses in order to accurately characterize the particular regional honeybee populations.

ACKNOWLEDGEMENTS. The authors thank Mehmet Ali Y1ldız (Ankara University, Faculty of Agriculture) for providing insights and guidance during the various phases of this project. The project was supported by a grant from the Scientific Research Projects (BAP) Coordinating Office of Selçuk University, Turkey (Project No: 08401051).

\section{REFERENCES}

Adl M.B.F., Gençer H.V., Firatli Ç. \& Bahreini R. 2007: Morphometric characterization of Iranian (Apis mellifera meda), Central Anatolian (Apis mellifera anatoliaca) and Caucasian (Apis mellifera caucasica) honey bee populations. J. Apicult. Res. Bee World 46: 225-231.

Arias M.C. \& Sheppard W.S. 1996: Molecular phylogenetics of honey bee subspecies (Apis mellifera L.) inferred from mitochondrial DNA sequence. Mol. Phylogen. Evol. 5: 557-566.

Bouga M., Harizanis P.C., Kilias G. \& Alahiotis S. 2005: Genetic divergence and phylogenetic relationships of honey bee Apis mellifera (Hymenoptera: Apidae) populations from Greece and Cyprus using PCR-RFLP analysis of three mtDNA segments. Apidologie 36: 335-344.

Bouga M., Alaux C., Bienkowska M., Büchler R., Carreck N.L., Cauia E., Chlebo R., Dahle B., Dall'Olio R., De la Rúa P., Gregorc A., Ivanova E., Kence A., Kence M., Kezic N., Kiprijanoviska H., Kozmus P., Kryger P., Le Conte Y., Lodesani M., Murilhas A.M., Siceanu A., Soland G., Uzunov A. \& Wilde J. 2011: A review of methods for discrimination of honey bee populations as applied to European beekeeping. J. Apicult. Res. Bee World 50: 51-84.

Clement M., Posada D. \& Crandall K.A. 2000: TCS: a computer program to estimate gene genealogies. Mol. Ecol. 9: $1657-1659$.

Collet T., Arias M.C. \& Del Lama M.A. 2007: 16S mtDNA variation in Apis mellifera detected by PCR-RFLP. Apidologie 38: 47-54.

Crozier R.H. \& Crozier Y.C. 1993: The mitochondrial genome of the honey bee Apis mellifera: complete sequence and genome organization. Genetics 133: 97-117.

De la Rúa P., Galián J., Pedersen B.V. \& Serrano J. 2006: Molecular characterization and population structure of Apis mellifera from Madeira and the Azores. Apidologie 37: 699-708.
Franck P., Garnery L., Solignac M. \& Cornuet J.-M. 2000: Molecular confirmation of a fourth lineage in honeybees from the near east. Apidologie 31: 167-180.

Franck P., Garnery L., Loiseau A., Oldroyd B.P., Hepburn H.R., Solignac M. \& Cornuet J.-M. 2001: Genetic diversity of the honey bee in Africa: microsatellite and mitochondrial data. Heredity 86: 420-430.

Garnery L., Cornuet J.-M. \& Solignac M. 1992: Evolutionary history of the honey bee Apis mellifera inferred from mitochondrial DNA analysis. Mol. Ecol. 1: 145-154.

Garnery L., Solignac M., Celebrano G. \& Cornuet J.-M. 1993: A simple test using restricted PCR amplified mitochondrial DNA to study the genetic structure of Apis mellifera. Experientia 49: 1016-1021.

HALL H.G. 1990: Parental analysis of introgressive hybridization between African and European honeybees using nuclear DNA RFLPs. Genetics 125: 611-621.

Hall H.G. \& Sмith D.R. 1991: Distinguishing African and European honey bee matrilines using amplified mitochondrial DNA. Proc. Natn. Acad. Sci. U. S. 88: 4548-4552.

Kandemir I., Kence M., Sheppard W.S. \& Kence A. 2006: Mitochondrial DNA variation in honey bee (Apis mellifera L.) populations from Turkey. J. Apicult. Res. Bee World 45: 33-38.

Kauhausen-Keller D., Ruttner F. \& Keller R. 1997: Morphometric studies on the microtaxonomy of the species Apis mellifera L. Apidologie 28: 295-307.

Kekecoğlu M., Bouga M., Soysal M.I. \& Harizanis P. 2009: Genetic divergence and phylogenetic relationships of honey bee populations from Turkey using PCR-RFLP's analysis of two mtDNA segments. Bulgar. J. Agric. Sci. 15: 589-597.

Magnus R. \& Szalanski A.L. 2010: Genetic evidence for honey bees (Apis mellifera L.) of Middle Eastern lineage in the United States. Sociobiology 55: 285-296.

Martimianakis S., Klossa-Kilia E., Bouga M. \& Kilias G. 2011: Phylogenetic relationships of Greek Apis mellifera subspecies based on sequencing of mtDNA segments (COI and ND5). J. Apicult. Res. 50: 42-50.

McElroy D., Moran P., Bermingham E. \& Kornfield I. 1991: REAP: The Restriction Enzyme Analysis Package, Version 4.0. University of Maine, Orono.

Munoz I., Dall'Olio R., Lodesani M. \& De la Rúa P. 2009: Population genetic structure of coastal Croatian honeybees (Apis mellifera carnica). Apidologie 40: 617-626.

Nedic N., Stanisavljevic L., Mladenovic M. \& Stanisavljevic J. 2009: Molecular characterization of the honeybee Apis mellifera carnica in Serbia. Arch. Biol. Sci. (Belgrade) 61: 587-598.

NEI M. 1978: Estimation of average heterozygosity and genetic distance from a small number of individuals. Genetics 89: 583-590.

NeI M. 1987: Molecular Evolutionary Genetics. 1st ed. Columbia Univ. Press, New York, $\mathrm{x}+512 \mathrm{pp}$.

Nei M. \& TAJIMA F. 1981: DNA polymorphism detectable by restriction endonucleases. Genetics 97: 145-163.

ÖZdil F., YILdiz M.A. \& Hall H.G. 2009a: Molecular characterization of Turkish honey bee populations (Apis mellifera L.) inferred from mitochondrial DNA RFLP and sequence results. Apidologie 40: 570-576.

Özdil F., Fakhri B., Meydan H., Yildiz M.A. \& Hall H.G. 2009b: Mitochondrial DNA variation in the CoxI-CoxII intergenic region among Turkish and Iranian honey bees (Apis mellifera L.). Biochem. Genet. 47: 717-721. 
Özdil F., Meydan H., Yildiz M.A. \& Hall H.G. 2011: Genetic diversity of Turkish honey bee populations based on RFLPs at a nuclear DNA locus. Sociobiology 58: 719-732.

Palmer M.R., Smith D.R. \& KaftanoğLu O. 2000: Turkish honeybees: Genetic variation and evidence for a fourth lineage of Apis mellifera mtDNA. J. Hered. 91: 42-46.

RUTTNER F. 1988: Biogeography and Taxonomy of Honeybees. Springer, Berlin, $284 \mathrm{pp}$.

Smith D.R., Slaymaker A., Palmer M. \& KaftanoğLu O. 1997: Turkish honeybees belong to the east Mediterranean mitochondrial lineage. Apidologie 28: 269-274.

Sheffield C.S., Hebert P.D.N., Kevan P.G. \& Packer L. 2009: DNA barcoding a regional bee (Hymenoptera: Apoidea) fauna and its potential for ecological studies. Mol. Ecol. Res. 9: 196-207.
Solorzano C.D., Szalanski A.L., Kence M., Kence A., McKern J.A. \& Austin J.W. 2009: Phylogeography and population genetics of honey bees (Apis mellifera L.) from Turkey based on COI-COII sequence data. Sociobiology 53: 237-246.

Suppasat T., Smith D.R., Deowanish S. \& Wongsiri S. 2007: Matrilineal origins of Apis mellifera in Thailand. Apidologie 38: 323-334.

Tanaka H., Roubik D.W., Kato M., Liew F. \& Gunsalam G. 2001: Phylogenetic position of Apis nuluensis of northern Borneo and phylogeography of A. cerana as inferred from mitochondrial DNA sequences. Insectes Soc. 48: 44-51.

Thompson J.D., Gibson T.J., Plewniak F., Jeanmougin F. \& HigGINS D.G. 1997: The CLUSTAL_X windows interface: flexible strategies for multiple sequence alignment aided by quality analysis tools. Nucl. Acids Res. 25: 4876-4882.

Received October 30, 2011; revised and accepted December 12, 2011 